\title{
Joodse narratiewe van die Persiese tydvak: Ideologie?
}

\author{
I J J Spangenberg \\ Departement Ou Testament \\ Universiteit van Suid-Afrika
}

\begin{abstract}
Jewish narratives of the Persian period: Ideology?

In recent years a number of scholars argued that the bulk of the Old Testament originated during the Persian and Hellenistic eras. The literature thus is the product of elite groups living in Yehud. They created a "history of Israel" in order to impose their ideology on the ordinary people. This being the case it would be impossible to write a history of the Jewish people prior to these periods. The article focuses on biblical books such as Chronicles, Ezra, Nehemiah, Jonah, Ruth, Esther, the Joseph novel, the Daniel stories, and the frame narrative of Job. These narratives leave one with the impression that the bulk of the material could be classified as fiction. However, the stories have most probably been created and written to assist the elite and the low classes in their acceptance of and adjustment to the new situation. It is not merely literature which elites wrote and which they tried to impose on others by way of ideology control.
\end{abstract}

\section{INLEIDING}

"Theologians do not create their environment; they are created within it." Hierdie aksioma is deur Chester Gillis (1993:66) in sy boek Pluralism: A new paradigm for theology neergepen. Geen mens gaan onaangeraak en ongeskonde deur die lewe nie - ook nie teoloë en Bybelwetenskaplikes nie. Tyd en gebeure beïnvloed nie net ons denke, verhoudings en besluite nie, maar ons totale lewe. Dit is dus volkome korrek om te sê dat ons almal kinders van ons tyd is. Maar as kinders van ons tyd groei en ontwikkel ons soos die tyd aanstap, ons kenniswêreld vergroot en die gespreksgenote toeneem.

Andries Breytenbach het sy BD-verhandeling (1968) geskryf in die jare toe die studie van Hebreeuse en Griekse woorde en uitdrukkings aan die orde van die dag was. 'n Goeie Bybelwetenskaplike moes in daardie jare bewys 
kon lewer dat hy oor die vermoë beskik om woorde in hulle kontekste te verstaan en uit te lê. Dit was die oorheersende tendens in die sestiger- en sewentigerjare van die vorige eeu. Suid-Afrikaanse Bybelwetenskaplikes was gedurende hierdie jare sterk onder die invloed van James Barr - en nie sonder rede nie. Hy het Bybelwetenskaplikes dwarsoor die wêreld aan die dink gesit oor waarmee hulle hulle besig gehou het en oor hoe hulle met die woorde van die Bybel omgegaan het (vgl Barr 1961, 1962).

Die jonger geslag Suid-Afrikaanse Bybelwetenskaplikes (nou die ouer geslag) het op die breuklyn van 'n nuwe era in die Bybelwetenskappe die navorsingsterrein betree (Spangenberg 1998:540, 542-543). Die moderne literatuurwetenskaplike benadering tot die interpretasie van Bybelboeke en gedeeltes van boeke, het stelselmatig invloedryker begin geraak. 'n Mens kan ook hierna verwys as 'n paradigmaverandering in die Bybelwetenskappe (Spangenberg 1994:156-162). Hierdie paradigmaverandering het hom aanvanklik in Suid-Afrika gemanifesteer in die vorm van woordstudies (vgl Deist 1971; Loader 1971; Vorster 1979a), maar dit het mettertyd aanleiding gegee tot heftige debatte oor die metodologie van uitleg. Die belangrikste vraag was: Wat kan as goeie uitleg van die Bybel beskou word? Hierdie vraag is ook na vore geroep deur die wyse waarop verskillende teoloë die Bybel gebruik het in hulle argumente oor die apartheidsbeleid (vgl Vorster 1979b).

Jurie le Roux (1993) het in sy navorsingsgeskiedenis van die OuTestamentiese Werkgemeenskap van Suid-Afrika twee hoofstrome onder die Suid-Afrikaanse navorsers onderskei. Die een stroom het meer diachronies te werk gegaan, en die ander een meer sinchronies. Na my oordeel lyk die navorsingstoneel tans anders. Suid-Afrikaanse Bybelwetenskaplikes weet tans dat hulle nie vir die een óf die ander benadering moet kies nie, maar vir beide. Voorts weet navorsers vandag dat kennis met denkraamwerke en teorieë saamhang en dat hulle versigtig met antieke tekste moet omgaan sodat hulle nie anachronisties (los van die tyd) en etnosentristies (aan die hand van ons kultuur) interpreteer nie. 'n Mens moet die wêreld waarin die tekste ontstaan het, goed ken as jy die tekste goed wil begryp. Maar die wêreld waarin die tekste ontstaan het, bly 'n wêreld wat die navorser skep. Die verlede is onherhaalbaar verby. Niemand kan dit weer beleef nie. Ons kan dit slegs maar konstrueer en dan ken aan die hand van ons konstruksies. In 'n sekere sin ontstaan 'n sirkelredenasie wanneer ons antieke tekste lees. Ons konstrueer die verlede aan die hand van argeologiese en literêre artefakte en interpreteer dan die tekste teen die agtergrond van die gekonstrueerde wêreld. Omdat ons kennis groei, moet ons dikwels die gekonstrueerde verlede weer besoek en die konstruksies hersien. In sommige gevalle moet ons die ouer konstruksies totaal afbreek en nuwes bou. In laasgenoemde 
geval kom 'n mens voor die byna ondenkbare te staan - die verlede kan verander!

Bybelwetenskaplikes leef tans in 'n tyd waar daar nie net groot meningsverskille oor die geskiedenis van Israel bestaan nie, maar ook oor die ontstaan van Judaïsme en die Christelike geloof. Argeologiese ontdekkings, manuskripontdekkings, metodes van uitleg, filosofiese kenteorieë, en die era waarin ons leef, noop ons om die vroeë konstruksies van Israel se geskiedenis, die Israelitiese godsdiens, die oorsprong van Judaïsme en die Christelike geloof te hersien (Nickelsburg 2003:1-8). Hierdie artikel fokus op die narratiewe wat gedurende die Persiese tydvak geskryf is en probeer bepaal wat die doel met die skryf van hierdie verhale sou wees.

\section{MINIMALISTE EN MAKSIMALISTE}

Die verskille onder navorsers oor die kwessie of die Ou-Testament geskrifte betroubare inligting meedeel oor sekere periodes het aanleiding gegee tot die benamings "minimaliste" en "maksimaliste" (Dever 2001:9). Die minimaliste (o a R P Carroll, P R Davies, N P Lemche, T L Thompson, K W Whitelam) deel die oortuiging dat die Hebreeuse Bybel gedurende die Persiese en Hellenistiese tyd geskryf is om identiteit aan die Joodse gemeenskap in die Persiese provinsie Jehud te verleen. Die historiese verhale (soos Josua, Rigters, Samuel, Konings, Kronieke) is volgens hulle hoofsaaklik fiktiewe verhale met weinig indien enige historiese feite oor die persone en periodes waaroor dit handel. Ons kan dus nie daarop peil trek om 'n geskiedenis van die vroeë periodes te skryf nie. In die woorde van Niels Peter Lemche (1993:192): "As a consequence of these and other discoveries, the Old Testament cannot be dated to the pre-exilic period; it is more likely a postexilic and to a large extent a hellenistic book written by Jews for Jews."

James Barr (2000:59) wat na die "minimaliste" as "revisionist historians" verwys, wys daarop dat hierdie groep geleerdes die siening huldig dat die tekste ' $n$ bepaalde ideologie kommunikeer. Hulle beskou ideologie nie as 'n stel idees wat mense se perspektiewe beïnvloed nie, maar as 'n kreatiewe beginsel wat die skrywers sekere tekste laat skryf het. Die skrywers is nie beïnvloed deur ' $n$ bepaalde ideologie nie - hulle het tekste geskep om uitdrukking te gee aan 'n bepaalde ideologie. Die tekste is na regte die ideologie (Barr 2000:88).

Na my mening kry ons hier met 'n vertekening van ideologie en wat ideologie kan doen, te doen. Natuurlik kan ideologie 'n skrywer en ' $n$ historikus se perspektief kleur - daarom kan die verlede dan ook verander (vgl Smith 1988). Om die Ou-Testamentiese literatuur egter as een groot stuk ideologie te beskou wat laat geskryf is en dit van nul en gener waarde te ag 
wanneer ' $n$ mens 'n geskiedenis van Juda vóór die Babiloniese ballingskap (597-538 vC) probeer skryf, lyk my na 'n eensydige siening. Tereg kritiseer James Barr (2000:59-101) en Ferdinand Deist (1997:122-137) hierdie soort uitgangspunt. Bestudeer ' $n$ mens die literatuur van enige volk val dit op dat latere skrywers geneig is om vroeëre verhale en gedigte in herinnering te roep en daarop in te speel. Ons kan hierdie proses soos volg voorstel:

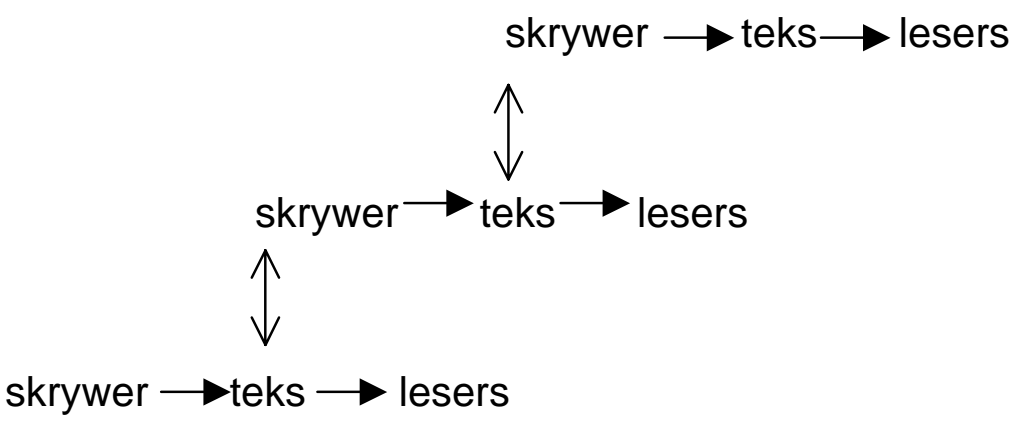

Die Joodse literatuur wat gedurende die Persiese en Hellenistiese tyd geskryf is, het nie in 'n lugleegte ontstaan nie. Dit was ook nie sonder wortels nie. Dit was geskryf deur mense wat familiebande met die vroeëre inwoners gehad het. Die skrywers het ouer tekste (mondelinge of geskrewe) in die skryfproses benut. Hierdie skrywers moet ons egter nie net soek onder die terugkerende ballinge nie, maar ook onder diegene wat agtergebly het. Hulle het nie net skeppend te werk gegaan nie, maar ook herskeppend. Van die verhale wat geskryf is, was bedoel om as stories gelees te word - daaroor bestaan geen twyfel nie. Alhoewel hierdie verhale historiese feite bevat, was die oogmerk nie in die eerste plek om 'n geskiedenis daar te stel nie. Aan die ander kant is daar tekste wat wel geskiedenis verhaal - al is dit nie in die moderne sin van die woord nie.

\section{PERSPEKTIEWE EN BELANGE}

Na my mening is dit een van die verdienstes van die minimaliste dat hulle ander navorsers bewus gemaak het daarvan dat niemand die OuTestamentiese literatuur lees en bestudeer sonder bepaalde perspektiewe en belange nie. Wanneer 'n mens die literatuur van die inwoners van die provinsie Jehud bestudeer, moet jy jouself doelbewus afvra: "Vanuit watter perspektief en in wie se belang lees ek?" Christen en Joodse navorsers lees byna deur die bank hierdie literatuur met die oog op die gemeenskappe waarvan hulle deel is. Hierdie gemeenskappe kan ons beskryf as "interpretive communities" (Hansson 1990:112). Byna alle Bybelleser is deel van so 'n gemeenskap. Voorts is dit so dat navorsers wat tot een van die twee dominante gemeenskappe behoort, ook onder die invloed van 'n 
meesterverhaal staan. ${ }^{1}$ Die minimaliste beskou hulleself egter as navorsers wat nie onder die invloed van 'n meesterverhaal staan nie. Hulle is agnostiese humaniste wat (volgens hulle oortuiging) die literatuur bestudeer bloot ter wille van die genot daarvan (Davies 1995:16). Vanuit hierdie perspektief kan hulle die literatuur beter beoordeel as die ander navorsers wat deel vorm van 'n interpreterende gemeenskap (Christene of Jode) en onder die invloed van 'n meesterverhaal staan.

Na my mening neem die minimaliste 'n meerderwaardige houding teenoor ander navorsers in en reken hulle dat hulle objektiewer lees as die res. Volgens hulle oordeel is hulle nie deel van 'n interpretatiewe gemeenskap nie. Hulle is ook nie "uitgelewer" aan 'n meesterverhaal wat hulle lees van die tekste kan beïnvloed nie.

Die minimaliste is deels reg. Die meesterverhaal van die Westerse Christendom het vroeër jare veroorsaak dat sommige Ou-Testamentici 'n negatiewe uitkyk op die Persiese en Hellenistiese tydvak gehad het. Hulle het dit as 'n periode van "verval" beskou. Die literatuur wat gedurende hierdie tyd geskryf is, het na hulle oordeel 'n legalistiese karakter gedra (vgl o a Bright 1953:174-175). Daar het eers weer lewe gekom na die geboorte van Jesus van Nasaret. Die belofte-vervullingskema was 'n handige skema wanneer die Ou Testament gelees en geïnterpreteer is. Tans speel die kanoniese benadering van Brevard Childs $(1978,1979)$ 'n belangrike rol. Deur middel van hierdie benadering kan Ou-Testamentici steeds die meesterverhaal van die Westerse Christendom onderskryf. "Kanonies" het in der waarheid net 'n skuilnaam vir die meesterverhaal van die Christelike geloof geword. Kanoniese interpretasie is dus ' $n$ interpretasie wat nie teenoor die meesterverhaal staan nie, maar dit ondersteun. Die feit dat daar tans navorsers is wat erken dat hulle afskeid geneem het van die meesterverhaal

\footnotetext{
${ }^{1}$ Die meesterverhaal van die Westerse Christendom kan ons soos volg weergee: Die ganse mensdom stam van een vader en moeder af, naamlik Adam en Eva. Hierdie eerste ouerpaar het egter alle mense se lot verseël toe hulle na die Satan geluister en God se gebod oortree het. Alle mense was bedoel om vir ewig te lewe, maar vanweë die eerste mense se ongehoorsaamheid in die tuin van Eden is almal bestem om te sterf. Die hele Ou Testament vertel die verhaal van hoe God die weg voorberei het vir die koms van sy Seun wat bestem was om die mag van die Satan en die dood te verbreek. Jesus het op die bestemde tyd as die ewige Seun van God uit die hemel gekom en mens geword. Hy het plaasvervangend onder God se oordeel aan die kruis vir die sondes van die ganse mensdom gesterf. Omdat Hy gehoorsaam was aan God se verlossingsplan en die kruisdood gewillig aanvaar het, het $\mathrm{Hy}$ die mag van die Satan en die dood verbreek. Die resultaat van hierdie soendood is dat alle mense nou vir ewig kan leef soos God dit van die begin van die skepping bedoel het. Die bewys dat Jesus se sending geslaagd was, is bevestig deur sy hellevaart, opstanding, hemelvaart en die uitstorting van die Heilige Gees. Jesus sal aan die einde van die tyd weer kom om diegene wat in Hom geglo het (en dus sy soenoffer aanvaar het) met die ewige lewe te beloon, maar diegene wat Hom en sy soenoffer verwerp het, met die ewige dood in die hel te straf.
} 
van die Westerse Christendom, maar wat tog reken dat die Bybelverhale nie bloot fiksie is nie en dat dit betroubare inligting meedeel, is iets wat die minimaliste se kaarte deurmekaarkrap. Een van hierdie geleerdes is William Dever. Hy erken openlik dat hy homself nie meer deel ag van die Christendom nie (vgl Dever 2001:ix-xi). Dit het egter nie sy oordeel rakende die geskiedenis van Israel aangetas nie.

Na my mening het Ferdinand Deist (1997), James Barr (2000) en William Dever (2001) die eensydige klemtone van die minimaliste uitgewys en gewys dat ons steeds via die verhale en ander artefakte 'n geskiedenis van Israel en Juda kan skryf. Die geskiedenis wat ons teken, bly egter steeds een wat ons skep aan die hand van die inligting en teorieë waarmee ons vertroud is. Daarom kan dit ook gekorrigeer word wanneer nuwere inligting beskikbaar is.

Alvorens die Persiese tydvak en die narratiewe wat tydens daardie jare geskryf is aan die orde kom, is dit nodig om kortliks na die Babiloniese ballingskap te kyk. Die ballingskap was allermins 'n fiktiewe gebeurtenis. Dit was ' $n$ realiteit wat diep letsels in die gemoedere van die ballinge gelaat het.

\section{DIE BALLINGSKAP: 'N BREUKLYN IN ISRAEL SE GESKIEDENIS}

In die jaar waarin Andries Breytenbach sy BD-verhandeling voltooi het, het Peter Ackroyd 'n boek gepubliseer met die titel Exile and Restoration: A study of Hebrew thought of the sixth century BC (1968). Dit het vir etlike jare as 'n standaard werk oor hierdie periode gedien. Ackroyd het oortuigend aangetoon dat die inname van Jerusalem, die wegvoer van gedeeltes van die bevolking, en die gevolglike ontwrigting van die sosiale lewe in Juda, 'n geweldige impak gehad het op die nadenke van sowel diegene wat agtergelaat is as diegene wat weggevoer is. Deur middel van hierdie publikasie wou hy aantoon dat die na-eksiliese periode 'n kreatiewe periode in die geskiedenis van Israel/Juda was (Ackroyd 1968:12). Daar is oor die hede, die verlede en die toekoms nagedink en geskryf. Hierdie blik op die ballingskaptydperk (597-539 vC) word nog deur vele Ou-Testamentici gedeel, daarom lees 'n mens ook in geskiedenisboeke soos dié van Hendrik Jagersma (1979:254) die volgende: "De tijd van deze ballingschap kan dan ook met recht als een keerpunt in de geschiedenis en godsdienst van Israël (Juda) getypeerd worden."

Oor hierdie keerpunt (of "breuklyn") is daar die afgelope tyd heelwat gepubliseer (vgl o a Grünewaldt 1992; Grabbe 1998). Selfs die tydskrif Bibel und Kirche het 'n hele volume aan die onderwerp gewy. In hierdie nommer van die tydskrif is daar opstelle van Reiner Albertz (2000), Jürgen Ebach (2000), Ernst Axel Knauf (2000), Christl Maier (2000), Stefan Schneider 
(2000) en Ursula Struppe (2000). Ou-Testamentici het Ackroyd se insigte verfyn, verder gevoer en soms ook gekritiseer. Ook hier in Suid-Afrika is lesenswaardige bydraes geskryf (vgl Le Roux 1987; Scheffler 1999).

Frank Crüsemann (1987:159) oordryf die saak wanneer hy beweer dat ongeveer $50 \%$ van die literatuur van Ou-Testament gedurende die ballingskap geskryf en/of geredigeer is. Die Persiese tydvak kwalifiseer veel eerder vir die soort opmerking (Grabbe 1992:29; Bolin 1996:3-15; Gerstenberger 2001:221; Ben Zvi 2003: 46), daarom is dit gepas om hierdie literatuur onder die loep te neem en te kyk watter stempel die gebeure op die skrywers en hulle tekste afgedruk het.

\section{DIE NARRATIEWE VAN DIE PERSIESE TYDVAK}

\subsection{Inleidende opmerkings}

Die stelling van Chester Gillis (1993:66) in die openingsparagraaf van hierdie artikel, naamlik "Theologians do not create their environment; they are created within it", kan net só op die Joodse denkers en skrywers van die Persiese tydvak van toepassing gemaak word. Hulle moes hulleself oriënteer aan 'n nuwe staatsbestel wat sekere reëls en regulasies neergelê het. Die Joodse gemeenskap in die provinsie Jehud kon slegs binne sekere parameters leef en handel. Hulle kon nie maar net doen wat hulle wou nie. Die Persiese owerheid het hulle wel toegelaat om 'n nuwe tempel te bou, maar hulle is nie toegelaat om 'n eie koning in Jerusalem te salf nie. Samuel Balentine (1996:143-144) som die situasie só op:

The actual world of Yehud in 539-333 BCE was defined by the Persians. This was the political reality: Yehud was occupied and controlled by a foreign power. The urgent task of the community was to survive, not in some abstract, imaginary world, but in the real world of the Persian Empire.

Totaal uitgelewer en slegs pionne op 'n skaakbord, was die inwoners van Jehud egter nie. Binne die neergelegde grense van die Persiese owerheid het hulle skeppend te werk gegaan. Alhoewel Gerd Theissen in sy boek $A$ theory of primitive christian religion oor die Christelike godsdiens skryf, geld sy woorde ook ten opsigte van die vroeë Judaïsme. Hy maak hieroor die volgende opmerkings (Theissen 1999:2):

Human beings cannot exist in their environment as they find it. They have to change it. They do that on the one hand by work and technology, and on the other by interpretation. The interpretation of 
the world is carried out by systems of interpretation: by common sense in everyday life; by science, art and religion.

Die Joodse skrywers van die Persiese tydvak het hulle wêreld verander en leefbaar gemaak deur skeppend en herskeppend met die inligting en literatuur tot hulle beskikking om te gaan. Alvorens ons egter by die literatuur kan stilstaan, is dit nodig om ook te kyk na die Joodse godsdiens (of te wel, vroeë Judaïsme) en die struktuur van die samelewing.

\subsection{Judaïsme van die Tweede Tempeltydperk}

Die herinterpretasies van die elite van die provinsie Jehud soos gereflekteer in hulle literatuur, kan 'n mens nie goed beskryf as jy nie ook kennis neem van hulle godsdienstige interpretasies nie. Ons moet in ag neem dat die godsdiens van vóór en ná die Babiloniese ballingskap eenvoudig nie meer dieselfde was nie (Gerstenberger 2002:252, 277). Die belewing van die inname van Jerusalem, die vernietiging van die tempel en die wegvoering na Babilon was te traumaties. Dit het tot ' $n$ krisis in hulle verstaan en verbeelding van God aanleiding gegee. Niks minder as 'n godsdienstige paradigmaverandering het plaasgevind nie; daarom lyk die Jode se geloofs- en godsdienstige paradigma ná die ballingskap totaal anders as vóór die ballingskap. Erhard Gerstenberger (2002:279) verwys hierna as 'n derde revolusie in Israel se verstaan van God. Die viering van die Sabbat, die besnydenis en die dieetvoorskrifte wat beslag gekry het in die ballingskap, is gekontinueer. Voorts het die twee tekskorpusse wat in die ballingskap tot stand gekom (die Deuteronomistiese geskiedwerk en die Priestergeskrif) hulle invloed laat geld. Die vergeldingsleer wat 'n groot rol speel in Deuteronomium en die Deuteronomistiese geskiedwerk (Weinfeld 1972:307-319) en die uitgebreide wetgewing in die Priestergeskrif, het 'n onuitwisbare indruk op die denke en lewe van die gemeenskap van Jehud gelaat.

Nog ' $n$ faktor wat ingespeel het op die nuwe geloofs- en godsdienstige paradigma was die oprigting van die tweede tempel. Die tempel en die Wet het uiteindelik die twee fokuspunte van die gemeenskap in Jehud geword (Balentine 1996:131-137). Daar het ook 'n mate van eksklusiviteit onder die mense ontstaan. Hierdie ekslusiwiteit het hoofsaaklik op sosiale en kultiese terrein voorgekom. Dit het waarskynlikheid saamgehang met die gevoel van bedreig-wees. In die woorde van Gerstenberger (2002:281): "Religious intolerance is born - as a means of self-assertion in a minority situation which seems hopeless." Eksklusiwisme kon egter nie verhinder dat nuwere idees hulle ingang in die geloofsoortuigings van die Jode vind nie. Invloede vanuit die Persiese godsdiens was onkeerbaar. 
Samevattend kan 'n mens die volgende sê: die Deuteronomistiese geskiedwerk en die Priestergeskrif het rigting aan die nuwe interpretasies gegee en die Wet en tempel het twee belangrike fokuspunte van die gemeenskap geword. Die literatuur wat gevolglik geskryf is, het dus óf iets van die vergeldingsleer van die Deuteronomistiese geskiedwerk weerspieël, óf verband gehou met die Priestergeskrif en die Wet, óf met die tempel en die verwagting van 'n wonderlike gebeurtenis êrens in die toekoms. Belangrike literatuurkorpusse is ook gedurende hierdie tydvak gekanoniseer. Rainer Albertz (1992:462) se stelling aan die begin van die hoofstuk oor die Israelitiese godsdiens in die na-ballingskaptyd, som die situasie mooi op:

\begin{abstract}
Herausgefordert von der Chance und den Problemen des Wiederaufbaus, wurden in dieser Zeit die Grundlagen gelegt, welche die spätere jüdische und christliche Religion massgeblich prägen solten: In dieser Zeit wurde der Weg der Kanonisierung in der Schaffung einer allgemein-verbindlichen heiligen Schrift beschritten, in dieser Zeit rückte der Tempel zum Mittelpunkt des religiösen Lebens und zum zentralen Symbol weitgespannter Hoffnungen auf und in dieser Zeit entstand ein eschatologischer Erwartungshorizont, der die Grenzen der politischen Geschichte und der menslichen Existenz immer deutlicher übersprang.
\end{abstract}

In die Afrikaanssprekende kerklike wêreld het die insig dat die Joodse godsdiens gedurende die ballingskap- en die na-ballingskaptydperk 'n paradigmaverandering ondergaan het, tot slegs ' $n$ handjievol predikante deurgedring. Die benamings "Judaïsme van die Tweede Tempeltydperk", of "vroeë Judaïsme" is vir baie mense totaal vreemd. Uit hierdie godsdiens het die Rabbynse Judaïsme en die Christelike godsdiens ontspring soos twee strome uit dieselfde fontein. Of in die woorde van Paul Joyce (1993): dit was twee dogters van dieselfde moeder. George Nickelsburg (2003:6) wys daarop dat oor hierdie saak nog baie dinkwerk vir teoloë voorlê: "The construction of new models of early Judaism and the circumstances of the rise of Christianity raise important questions for theologians. What happens, or should happen, when one discovers that theology is based on wrong history?"

\title{
5.3 Die samelewing en sosiale verhoudinge
}

Een van die sake wat Ou-Testamentici tans indringend bespreek, is hoe die samelewing van die Persiese provinsie Jehud daar uitgesien het en wie aan die stuur van sake gestaan het (vgl o a Cataldo 2003). Rainer Albertz (2003:117) argumenteer dat die Persiese goewerneur die primêr verantwoordelike persoon was, maar dat daar ook 'n raad van Joodse priesters en 'n raad van Joodse edelmanne was. Naas hierdie drie "bestuursliggame" was daar egter 
ook die volksvergadering (die $q \bar{a} h \bar{a})$, maar hierdie vergadering is slegs van tyd tot tyd byeengeroep.

Die gemeenskap in Jehud was klaarblyklik nie 'n egalitêre gemeenskap nie. Sommige families van diegene wat agtergebly het, was vermoënd en het "grondbaronne" geword. Ander wat die benaming "die volk van die land" gekry het, was sukkelende kleinboere. Die terugkeer van 'n handvol ballinge het spanning in die gemeenskap laat oplaai. Grondbesetting en grondeise was op daardie tydstip seker nie iets ongewoon nie.

Binne die gemeenskap het daar gevolglik 'n groeiende spanning ontstaan tussen die meer gegoede elite aan die een kant, en die arm kleinboere en die terugkerendes aan die ander kant. Daar was egter lede van die vermoëndes wat hulle oor die arm kleinboere en terugkerendes ontferm het. Dit het daartoe gelei dat na die elite verwys is as "regverdiges" wanneer hulle goed gedoen het, en as "goddeloses" wanneer hulle ander benadeel het.

\subsection{Vertelliteratuur van die Persiese tydvak}

Die vertelliteratuur wat gedurende hierdie tydvak geskryf is, kan in drie kategorieë verdeel word: (1) Geskiedenisse, (2) Diaspora-novelles, en (3) Didaktiese novelles. Slegs één onderafdeling van die vertelliteratuur kan dus met historiese feite in verband gebring word. Die geskiedenisse wat geskryf is, is wel vanuit 'n bepaalde hoek geskryf, maar ontdaan van enige historiese gegewens is dit weliswaar nie.

\subsubsection{Geskiedenisse}

\subsubsection{Die Kronistiese Geskiedwerk}

Dit was tot betreklik onlangs 'n aanvaarde standpunt onder Ou-Testamentici dat 1 en 2 Kronieke, Esra en Nehemiah één literêre werk is (Klein 2001:385). Geleerdes het deur die bank na hierdie vier boeke verwys as "die Kronistiese Geskiedwerk" en die skrywer(s) daarvan die naam "die Kronis" gegee. Hierdie standpunt is twee dekades gelede nog deur Peet van Dyk (1987) verwoord in 'n reeks bekend as Die literatuur van die Ou Testament - twee dekades nádat Sarah Japhet (1968) in 'n artikel die teorie van één skrywer vir die vier boeke grondig gekritiseer en oortuigend aangetoon het dat dit hoogs onwaarskynlik is. Tog staan Peet van Dyk nie alleen nie, want H G M Williamson (1987:37), Joseph Blenkinsopp (1983:113; 1988: 47-54) en Barry Bandstra (1995:486487) hou ook nog aan die tradisionele siening vas.

Dit is baie moeilik om die boeke $1 \& 2$ Kronieke presies te dateer. Die twee boeke (wat na regte één boek is) is waarskynlik geskryf vlak voor die 
einde van die Persiese oorheersing, óf kort na die verowerings van Aleksander die Grote en die gevolglike aanbreek van die Hellenistiese tydvak (333 vC). Enige datum tussen $400 \mathrm{vC}$ en $250 \mathrm{vC}$ is moontlik. Die boeke is waarskynlik geskryf deur Levitiese priesters, want dit fokus hoofsaaklik op die Jerusalemse tempel, die rol van die Leviete in die erediens, en die aanbidding van God. Die Leviete was 'n groep plattelandse priesters wat vóór die ballingskap 'n ondergeskikte rol gespeel het ten opsigte van die Jerusalemse priesters.

Omdat die koningskap tot niet was en die inwoners van Jehud onder die gesag van die Perse gestaan het, het die priesters en Leviete 'n al hoe belangrike rol in die bestuur van die land begin speel. Daar was waarskynlik 'n raad van priesters naas die raad van edelmanne wat met die landsbestuur gemoeid was. Die priesters en Leviete moes waarskynlik die belastings ingevorder en aan die Persiese goewerneur oorbetaal het.

Omdat die Leviete 'n groter rol in die erediens en die bestuur van die land begin speel het, het hulle ook 'n geskiedenis geskryf wat hulle sienings en aansprake gelegitimeer het. Wanneer ons die Kronistiese Geskiedwerk met die Deuteronomistiese Geskiedwerk vergelyk, is die verskille opvallend en tree die perspektief van die Leviete duidelik na vore. (Vgl in hierdie verband die verhaal van die vervoer van die ark na Jerusalem soos dit vertel word in 1 Kronieke 13:1-14 en 2 Samuel 6:1-11.) Die twee gedeeltes stem byna woordeliks ooreen, maar daar is interessante verskille.

Die gedeeltes vertel van die dood van Ussa en die "parkeer" van die ark by Obed-Edom. Waar die verhaal in Samuel vervolg met Dawid se gaan haal van die ark (2 Sam 6:12-19) onderbreek Kronieke die verhaal deur te vertel van die aanstelling van die Leviete en die rol wat hulle gespeel het in die vervoer van die ark na Jerusalem (1 Kron 15:1-24). Die Deuteronomistiese Geskiedwerk gee nie 'n verklaring vir Ussa se dood nie, maar die Kronistiese Geskiedwerk verskaf 'n rede: slegs die Leviete mag die ark hanteer!

Dit is ook heel moontlik dat Kronieke geskryf is om die nuwe tempel en die aanbidding daar aan te moedig (Klein 2001:389). Jerusalem word sodoende aangewys as die enigste legitieme plek van aanbidding.

Die skrywer(s) van Kronieke was hoofsaaklik begaan oor die koninkryk van Dawid en die godsdienstige gemeenskap in Jerusalem. Die gebeure in die Noordryk word slegs dan en wan vermeld en dan ook baie kursories. Kronieke veridealiseer die regerings van Dawid, Salomo en Hiskia. Dawid word geteken as 'n vroom en vlekkelose koning. Hy was gehoorsaam aan God; hy het die godsdiens in Jerusalem gevestig met sy priesters, Leviete, sangers, gebede, rituele en offers. Die skrywers het dus uiters selektief met die inligting tot hulle beskikking, omgegaan. Al het hulle oor dieselfde inligting 
as die skrywers van die Deuteronomistiese Geskiedwerk beskik, het hulle verkies om die gegewens wat Dawid se beeld skade kon berokken, weg te laat. Dawid se opstand teen Saul en sy geheul met die Filistyne word verswyg (1 Sam 19:18-26:25; 27:1-29:11). So ook Dawid se onderonsie met Nabal en Nabal se uiteindelike dood. Sy dood het aan Dawid die geleentheid besorg om met Abigail (Nabal se vrou) te trou (1 Sam 25:1-42). Dit geld ook die hele episode in verband met die dood van Uria en die verhouding met Batseba (2 Sam 11:2-12:25). "For the Chronicler, therefore, David's chief claim to fame was not as warrior and founder of a dynasty but as the one who laid the foundations for temple worship" (Blenkinsopp 1983:115).

Die Leviete het Dawid verantwoordelik gemaak vir die beplanning van die tempel. Dawid, en nie Salomo nie, was in hulle oë die persoon wat al die beplanning in verband met die tempel en die erediens gedoen het. Salomo het dit slegs maar deurgevoer (1 Kron 23-28; 2 Kron 3:1-7:10). Belangrik in hulle oë was ook die kultiese hervormings wat koning Hiskia deurgevoer het (2 Kron 29-31). Die Deuteronomistiese Geskiedwerk rep geen woord hieroor nie.

Die klem in Kronieke val dus duidelik op die Levitiese priesters, die tempel en die eredienspraktyke in Jehud. Die geskiedenis van die Judese konings word vanuit hulle perspektief vertel - dit wil sê, wat was die koning se houding jeens die kultus in Jerusalem. Het hulle positief daarteenoor gestaan, of het hulle allerlei afwykende praktyke toegelaat? Hierdie geskiedenis dra duidelik 'n bepaalde stempel. Geskiedenis soos ons dit vandag definieer, was dit nie. Maar ontdaan van historiese feite is dit sekerlik ook nie.

\subsubsection{Esra en Nehemia}

Esra en Nehemia is die belangrikste bronne waaroor ons beskik vir die vroeë ná-ballingskapperiode. Dit was ' $n$ oorgansperiode in die lewe van die mense in Jehud en tydens hierdie periode het verskeie ontwikkelinge plaasgevind. ' $n$ Nuwe tempel is gebou, die priesters het naas die Joodse edelmanne ' $n$ rol in die bestuur van die land begin speel, terwyl die Wet as 'n soort "grondwet" begin gefunksioneer het.

Alhoewel die boeke Esra en Nehemia byna 'n volle eeu van die naballingskapperiode dek, bestaan dit nie uit 'n aaneenlopende geskiedenisverhaal nie. Die verhale word dikwels onderbreek deur dokumente (Esra 4:17-23; 7:11-26), briewe (Esra 4:8-16; Neh 6:2-9), lyste (Esra 1:9-11; 8:24-28; Neh 3:1-32) en materiaal van kultiese of godsdienstige aard (Esra 6:19-22; Neh 8; 12:27-43).

Die boeke Esra en Nehemia bestaan na regte uit drie verteleenhede wat elkeen op ' $n$ ander hoofkarakter en ander belangrike gebeure fokus. Die 
eerste ses hoofstukke (Esra 1-6) handel oor die terugkeer van die eerste ballinge onder die aanvoering van Serubbabel en die hoëpriester Jesua en die herbou van die tempel. Hierdie verteleenheid eindig met die inwyding van die tempel (Esra 6:16-18) en die vier van die Pasga (Esra 6:19-22). Hierdie verteleenheid kan getipeer word as die "Boek van Serubbabel" en dek die periode 538-515 vC.

Die tweede verteleenheid handel oor die priester en skrywer Esra onder wie se leiding 'n volgende groep Jode na hulle land teruggekeer het. Dit het plaasgevind in die sewende jaar van die regering van die Persiese koning Artaserkses I (458 vC). Hierdie verteleenheid fokus op Esra se handelinge soos sy optrede teenoor diegene wat getroud was met "uitlandse vroue". Hierdie verteleenheid wat bekend staan as die "Herinneringe van Esra" en kom voor in Esra 7-10 en Nehemia 8-10.

Die derde verteleenheid wat bekend is as die "Herinneringe van Nehemia" handel oor die lewe van Nehemia seun van Gakalja en bestaan uit Nehemia 1-7 en 11-13. Hy het in die twintigste jaar van die Persiese koning Artaserkses I (445/444 vC) na Jerusalem gekom omdat hy as goewerneur van die provinsie van Jehud aangestel is. Nadat hy vir 'n kort periode na Persië teruggekeer het, is hy vir 'n tweede termyn teruggestuur. Alhoewel ons nie weet hoelank die tweede termyn geduur het nie, was hy waarskynlik tot 420 vC werksaam.

Elkeen van die drie verteleenhede fokus nie net op 'n hoofkarakter nie, maar op gebeure wat in daardie hoofkarakter se leeftyd afgespeel het en die lewe van die mense in Jehud beïnvloed het. Die eerste verteleenheid (Esra 16) draai rondom die optrede van Serubbabel en die herbou van die tempel. Die gedeelte word afgesluit met die inwyding van die tempel en die viering van die Pasga (Esra 6:13-22).

Die tweede verteleenheid (Esra 7-10, Nehemia 8-10) handel oor die optrede van die priester en skrywer Esra. Die gedeelte sluit met 'n vertelling hoe die volk na die voorlees van die Wet van God geluister het (Neh 8:1-13), boete gedoen (Neh 9) en onderneem het om getrou die Wet uit te leef (Neh 10:28-39).

Die derde verteleenheid (Neh 1-7, 11-13) vertel van die rol wat Nehemia gespeel het in die herbou van Jerusalem se mure en sy maatreëls teen die uitbuiting van die arm kleinboere (Neh 5:1-13). Dit sluit af met 'n vertelling oor die herstel van die Leviete se voorregte en diens, die beklemtoning van die onderhouding van die Sabbat en die optrede teenoor diegene wat met uitlandse vroue getroud is (Neh 13:10-14, 15-22, 23-31).

Uit hierdie drie verteleenhede sien ons watter belangrike rol Jerusalem, die tempel en die Wet van God in die lewe van die mense van Jehud begin 
speel het. Hierdie drie sake het die fokuspunte in die godsdienstige lewe van die Jode begin word. Ook hierdie vertellinge is vanuit 'n bepaalde hoek geskryf, maar om te reken dat al die karakters fiktief is en dat die verhale geskep is om 'n ideologie op ander mense af te druk, getuig van oordrewe skeptisisme.

\subsubsection{Diaspora-novelles}

Drie interessante novelles is gedurende die Persiese tydvak geskryf: die Josef-, die Ester- en die Daniëlverhaal. Al drie handel oor ' $n$ Joodse persoon wat in ballingskap verkeer. Hier in die vreemde land word die persoon se lewe bedreig vanweë sy handelinge, of oortuigings, of bloot net omdat hy/sy Joods is. Die bedreiging(s) word oorkom en die persoon beklee eventueel ' $n$ belangrike pos aan die hof van die heerser. Arndt Meinhold $(1975,1976)$ het aan twee van hierdie novelles (Josef en Ester) die naam "Diaspora-novelle" gegee. Na my mening kwalifiseer al drie egter vir hierdie benaming.

Die drie verhale het interessante raakvlakke. Die plot van die verhale wentel om 'n bedreiging in 'n ballingskapsituasie. Voorts bevat die verhale wysheidselemente. Hieroor is daar ook al heelwat geskryf (vgl o a Humphreys 1973; Loader 1974, 1987a, 1987c; Wessels 1989:41-50). Tog word één saak oor die hoof gesien - die verhale bied lesers 'n positiewe blik op die ballingskap. Die verhale kommunikeer die volgende boodskap: Daar was slegte tye, maar God was in al die gebeure teenwoordig en het dit in die guns van die ballinge laat verloop.

\subsubsection{Josefverhaal}

Die Josefverhaal vind 'n mens in Genesis 37-50. Intensiewe studie van hierdie verhaal het sommige Ou-Testamentici daartoe gebring om drie weergawes van die verhaal te rekonstrueer. Daar was volgens hulle 'n weergawe uit die hand van die Jahwis; 'n weergawe uit die hand van die Elohis en 'n weergawe uit die hand van die Priesterskrywer (Scharbert 1988). Oor die bestaan van verskillende bronne in die Pentateug oordeel Ou-Testamentici tans anders as vorige geslagte. Sommige Pentateugnavorsers meen dat daar nie 'n afsonderlike J-bron bestaan het nie. Na my mening het daar wel 'n voorballingskap verhaal oor Josef bestaan. Hierdie verhaal is egter deur 'n Priesterskrywer ná die ballingskap hersien, geredigeer en in die Pentateug ingevoeg as 'n brug tussen die aartsvaderverhale (Gen 12-36) en die eksodusverhaal (Loader 1987a:103). 


\subsubsection{Esterverhaal}

Alhoewel Persepolis die hoofstad van die Persiese ryk was, speel die Esterverhaal in Susa af waar die koning se winterpaleis was. Die verteller van hierdie verhaal is goed op hoogte met die toestande en gebruike in die Persiese ryk en daarom is dit na alle waarskynlikheid tydens die Persiese era geskryf (Loader 1987c:117).

Die verhaal kan deels beskryf word as die agtergrondsverhaal vir die instelling van die Purimfees. Dit is egter so kunstig saamgestel dat daar ook ander ondertone in die verhaal voorkom (Loader 1978). Aan die een kant vertoon dit ooreenkomste met die Josefverhaal (waarin wysheidselemente voorkom), maar aan die ander kant vertoon dit ook ooreenkomste met die Eksodusverhaal (wat ook handel oor bevryding en die instelling van 'n fees) (Dommershausen 1968).

Die Esterverhaal handel oor die redding van die Jode toe hulle deur uitwissing bedreig was. Daar is baie elemente wat aan die Eksodusverhaal herinner, maar anders as in dáárdie verhaal, speel God hier nie 'n sigbare rol nie. Hy tree na regte agter die skerms op. Die verteller maak ons van sy teenwoordigheid bewus deur al die toevallighede wat in die verhaal afspeel: Ester word op die juiste oomblik koningin (Est 2:1-18; 4:14); koning Ahasveros ly op die gepaste oomblik aan slaaploosheid (Est 6:1); die annale waarin Mordegai se optrede vermeld word, word in daardie nag vir die koning voorgelees (Est 6:1-3); Haman is in die paleis presies op daardie laat uur van die nag wanneer die koning met hom oorleg wil pleeg (Est 6:4-5). Die allesoorheersende godsdienstige suggestie is egter die wending wat in die verhaal voorkom. Ons vind ' $n$ omkering van verhoudinge in die verhaal: Mordegai ontvang die eer waarop Haman gehoop het (Est 6:10-11) en Haman hang aan die galg wat hy vir Mordegai opgerig het (Est 7:8-10). Mordegai word aangestel in die amp wat Haman vroeër bekleë het (Est 8:1-2). Die vyande wou die Jode uitroei, maar vind dan dat die Jode hulle uitroei (Est 9:119).

Hierdie omkering van verhoudinge tussen sterkes en swakkes, oorwinnaars en oorwonnes, verdrukkers en verdruktes is oral in die Ou Testament te vind. ' $n$ Mens kom dit ook in die Eksodusverhaal teë. In al die gevalle waar dit in die Ou Testament voorkom, word uitdruklik gesê dat dit God is wat die verhoudinge omkeer. In die geval van die Esterverhaal word God se handelinge egter verswyg. Daar staan nêrens uitdruklik dat dit God is wat ingryp nie. Die hele verloop van die verhaal suggereer dit egter. Dit lyk of mense die groot redders in die verhaal is, maar in werklikheid is dit God. Wat die verhaal dus wil kommunikeer is dat God se bestuur menslike aktiwiteit nie 
uitsluit nie. Juis die verhulling van God se optrede maak dit duidelik dat Hy die mens as medewerker in diens neem (Loader 1980, 1987c).

\subsubsection{Daniëlverhaal}

Die boek Daniël bestaan uit twee dele: 'n verhalende deel (Dan 1-6) en 'n visioenêre deel (Dan 7-12). Die verhalende deel wat handel oor die wedervaringe van Daniël en sy vriende aan die hof van verskeie konings is ouer as die dele met die visioene. Wanneer 'n mens die verhalende deel noukeurig lees, blyk dit dat daar twee soorte verhale is: (a) verhale wat oor die verklaring van drome en 'n geheime skrif handel (Dan 2, 4 en 5) en (b) verhale wat oor wonderbaarlike reddings handel (Dan 3 en 6). Die ingewikkelde ontstaansgeskiedenis van die ganse boek en hoe die verhalende deel met die deel met visioene saamhang, is nie nou ter sake nie. Slegs die verhale kom aan die bod. Daar is redelike eenstemmigheid dat Daniël 1-6 die ouer deel is en dat dit tydens die Persiese tydvak geskryf is (Davies 1985:40-80; Collins 2001:5, Knibb 2001:17).

In die verhalende deel word die onvergelykbaarheid van God beklemtoon. Hierdie tema kom reeds in hoofstuk 1:17 na vore: "God het aan hierdie vier jongmanne verstand gegee en insig in alles wat geskryf is, en ook wysheid." Daniël kon enige gesig of droom uitlê. Die feit dat Daniël bo ander kon uittroon, het hy aan sy God te danke gehad. In Daniël 2:47 sê Nebukadnesar: "Werklik, julle God is die grootste van al die gode ..." en in Daniël 3:29 sê dieselfde koning: "Daar is immers geen ander god wat in staat is om só te red nie. God troon eenvoudig bo die ander gode uit."

Afgesien daarvan dat God onvergelykbaar is, is Hy ook magtig, verhewe en wys. Dit kom eerstens tot uitdrukking in Daniël se lofprysing in Dan 2:20-23, maar ook in Nebukadnesar se belydenis. Hy sê: "Teenoor Hom is al die bewoners van die aarde soos niks; Hy doen soos Hy besluit met die hemelse magte en met die mense op aarde. Daar is niemand wat Hom daarvan kan weerhou en vir Hom sê: "Wat doen U?' nie" (Dan 4:34). Hy gee aan mense die lewensasem (Dan 5:23) en stel konings aan en raak van hulle ontslae (Dan 4:32; 5:18). Hy is ' $n$ lewende God wat red en bevry (Dan 6:2728). Hierdie is belangrike insigte wat oorgedra is in 'n gemeenskap wat nog die tekens van die val van Jerusalem en die tempel kon sien.

\subsubsection{Didaktiese novelles}

Daar is drie boeke wat gedurende die Persiese tydvak geskryf is wat as didaktiese geskrifte getipeer kan word. Twee hiervan kan as didaktiese novelles geklassifiseer word. Dis die boeke Jona en Rut. Die derde boek (Job) is moeiliker te klassifiseer. Fokus ons net op die raamvertelling van die boek 
(Job 1-2 \& 42:7-17) kan ons dit seker as 'n novelle sien, maar sonder die poëtiese middelstuk is dit nie didakties nie. Die boek Job het na alle waarskynlikheid oor die jare gegroei tot die omvangryke werk soos ons dit tans ken. Inhoudelik kwalifiseer die verhaal na my mening om ook as 'n didaktiese novelle beskryf te word, maar struktureel lyk dit meer na 'n drama. In teenstelling met die vorige boeke wat leser probeer bemoedig het, daag hierdie drie verhale lesers uit om anders oor die lewe en oor nie-Jode te dink.

\subsubsection{Verhaal oor Jona}

Ons het reeds vroeër gesien (vgl 5.3) dat die samelewing van Jehud uit verskillende klasse en groeperinge bestaan het. Daar was armes en vermoëndes (wat op hulle beurt uit twee groeperings bestaan het: "regverdiges" en "goddeloses"). Dit was egter nie die enigste groepe wat in die Persiese tyd in die samelewing van Jehud voorgekom het nie. Daar was ook verskille oor wat die Jode se houding teenoor ander mense behoort te wees. Sommige mense het die standpunt ingeneem dat die Jode hulle van ander mense moes afsonder. Hierdie groep kan ons die eksklusiviste (of die "seperatiste") noem. Hulle is grootliks beïnvloed deur die sienings en handelinge van Esra en Nehemia. Teenoor hulle was daar mense wat ons die universaliste (of die "integrasioniste") kan noem. Hulle was van mening dat die Jode hulle nie van ander mense moes afsonder nie, maar met hulle moes saamleef. Die universaliste het nie kans gesien vir die verengde sienings van die seperatiste nie.

Dit is moontlik dat die skrywer van die Jonaverhaal die karakter Jona as 'n verteenwoordiger van die eksklusiviste teken. Die skrywer wou hiermee die lesers van die verhaal beïnvloed om te besef dat die God van Israel nie maar net begaan is oor 'n klein klompie inwoners van Jehud nie, maar oor alle mense (Deist 1981:9-11; Loader 1987d:126). Hy is immers die Skepper van hemel en aarde; die God wat barmhartig, genadig, lankmoedig en vol liefde is. Hy staan nie apaties en toekyk wanneer mens en dier sterf nie - selfs al is daardie mense en diere nie inwoners van Jehud nie.

\subsubsection{Verhaal oor Rut}

Die boek Rut word gewoonlik ook as 'n novelle geklassifiseer omdat dit so kort is, 'n eenvoudige verhaalstruktuur het en min karakters daarin optree (Loader 1987b:108; 1994:9). Die novelle begin deur te vertel van 'n hongersnood in Juda wat 'n gesin van Betlehem gedwing het om ter wille van oorlewing na Moab uit te wyk ('n selfopgelegde ballingskap dus). Die gesin het bestaan uit Elimelek, Naomi en twee seuns, Maglon en Kiljon. Hier in die 
vreemde tree die seuns in die huwelik met Moabitiese vroue, maar dan sterf Naomi se man en haar seuns skielik en bly sy as weduwee alleen agter.

Alhoewel die boek die titel dra van "Rut", handel die novelle eintlik oor die wedervaringe van Naomi, die vrou van Elimelek. Haar antwoord op die Betlehemvroue se uitroep van verbasing is 'n belangrike fokuspunt in die vertelling. Sy sê aan hulle: "Moet my asseblief nie meer Naomi noem nie, noem my Mara, want die Almagtige het die lewe vir my baie bitter gemaak. My lewe was vol toe ek hier weg is, maar die Here het my leeg laat terugkom. Waarom noem julle my nog Naomi? Die Here het dan teen my gedraai, die Almagtige het 'n ramp oor my gebring" (Rut 1:20-21). Hierdie woorde spreek van ontnugtering en ontreddering. Sy is teleurgesteld deur God se optrede teenoor haar. Sy voel haar in die steek gelaat. Dit is dan ook nie verbasend dat iemand Naomi al "die suster" van Job genoem het nie. Sy het immers deur soortgelyke diep waters as hy gegaan.

Deur middel van hierdie verhaal van ontnugtering en ontreddering probeer die verteller die verskillende groeperinge in die gemeenskap van die provinsie Jehud aanspreek. Eerstens probeer hy die terugkerende ballinge hoop bied deur te beklemtoon dat God deur gewone mense se optredes wonderwerke kan verrig. Naomi keer as 'n verbitterde mens terug na Betlehem. Sy sien haarself as 'n eensame kinderlose weduwee wat 'n uitsiglose toekoms tegemoet moet gaan. Teen die einde van die verhaal is sy egter weer Naomi, die aangename, die vrolike een, want God het haar lewensomstandighede radikaal verander deur die toedoen van 'n troue skoondogter en 'n vermoënde familielid (vgl Rut 1:20-21 met 4:13-16).

Deur hierdie vertelling moedig die verteller tweedens die vermoëndes van Jehud aan om hulle plig teenoor die armes en terugkerendes na te kom. Die vermoëndes behoort soos Boas hulle te ontferm oor ander. Hulle het 'n sosiale verantwoordelikheid wat hulle nie behoort te ontduik soos die ander losser in die verhaal nie (vgl Rut 4:1-6).

Laastens spreek die verteller ook die gemeenskap se sosiale vooroordele aan. Rut speel in hierdie vertelling byna dieselfde rol as die Samaritaan in die gelykenis van die barmhartige Samaritaan (vgl Luk 10:2537). Volgens Deuteronomium 23:3 kon 'n persoon van Moabitiese afkoms nie deel word van die Joodse volk nie, en Esra en Nehemia het die mense van Jehud gestriem oor hulle uitlandse vroue (vgl Esra 10:10-11; Neh 13:23-31). Hierdie verhaal beklemtoon egter dat God deur die toegeneëntheid van 'n nievolksgenoot 'n nuwe toekoms vir sy volk kan oopbreek. God verander die lewensomstandighede van Naomi deur die handeling van 'n troue Moabitiese skoondogter op wie mense eintlik veronderstel was om neer te sien. 


\subsubsection{Die verhaal van Job}

Die hoofkarakter (Job) word voorgehou as 'n vermoënde persoon met 'n groot huishouding en verskeie veekuddes. Hierdie uitbeelding van die hoofkarakter het lesers daartoe gelei om te dink dat Job in die tyd van Abraham moes geleef het en dat die verhaal uit die tyd van die aartsvaders kom. Die taal waarin dit geskryf is en ander gegewens in die boek, het Ou-Testamentici egter oortuig dat dit in die Persiese tydvak geskryf is. Die boek kry werklik lewe wanneer ons dit lees teen die agtergrond van die sosio-ekonomiese toestande wat tóé in die provinsie Jehud geheers het (Albertz 1981:349-372).

Die Joodse samelewing tydens die hoogbloei van die Persiese oorheersing het uit twee strata bestaan: die vermoëndes en die armes (vgl die Rutverhaal). In die geledere van die vermoëndes was daar diegene wat niks omgegee het vir die armes nie, maar daar was ook ander wat hulle die lot van die armes aangetrek het. Hierdie groep is dikwels as die "regverdiges" voorgehou en dit is in hulle geledere waar die hoofkarakter Job tuishoort.

In die poëtiese gedeelte van die boek (Job 3:1-42:6) word Job geteken as 'n vermoënde man wat tot die elite van die samelewing behoort het. Hy was besonder ryk. Hy het goud besit (Job 31:24-25), landerye en veekuddes gehad (Job 30:1; 31:20) en slawe en veewagters aangehou (Job 30:1; 31:13). Hy was 'n gerespekteerde burger op wie se raad mense staat gemaak het. Hy het in die stadspoorte as regter opgetree en het ook deel gevorm van die stad se bestuursliggaam (Job 29:7-10, 21-23). Maar Job word ook geskets as 'n man wat begaan was oor die lot van die armes, weses en weduwees. Die beskuldigings van sy vriende dat hy ander uitgebuit het, het hy met mag en mening bestry. Hy wys onder andere daarop dat hy die armes van klere en slaapgoed voorsien het (Job 31:19). Hy het sy voedsel met wese gedeel en weduwees se lot hom aangetrek (Job 31:16). Hy het in die bres getree vir diegene wat verdruk en uitgebuit is (Job 29:13-16).

Om die boek goed te begryp, moet 'n mens besef dat die vergeldingsleer die as is waaromheen die hele verhaal draai. Die skrywer van die boek wou met sy verwerking van die verhaal van Job die rigiditeit van die vergeldingsleer blootlê en sodoende 'n pleidooi lewer vir 'n meer gebalanseerde uitkyk op die lewe en sy probleme. Sowel Job as sy drie vriende (Elifas, Bildad en Sofar) neem die vergeldingsleer as vertrekpunt in hulle redenasies.

Afgesien daarvan dat die verhaal die vergeldingsleer ondermyn, het dit waarskynlik ook daardie deel van die elite van die Joodse samelewing in Jehud wat hulle (soos Job) die nood van ander aangetrek het, aanspoor om nie te verslap nie. Die gevaar het bestaan dat hulle ook sou kon begin vra: "Maar watter voordeel is daar vir my in hierdie soort optrede" (Job 1:9-11)? 
Godsdiens word nie beoefen om een of ander voordeel te kry nie. Soos Job moes hulle leer om nie na die voordele te vra wannneer hulle vroom en opreg leef nie. Soos hy moes hulle ook leer om God nie ondergeskik te stel aan 'n dogma nie (Job 38:1-42:6).

\section{SLOT}

Ons kan uit die voorafgaande bespreking van die verhale wat in die Persiese tydvak geskryf is enkele gevolgtrekkings maak. Eerstens is dit duidelik dat hierdie verhale die kreatiewe skeppings van Joodse skrywers was. Hulle het nie alleen kreatief met ouer verhale omgegaan nie, maar ook nuwe verhale geskep. Tweedens is dit duidelik dat die nuwe leefruimte die skrywers "uitgenooi" het om die verhale te skep. Verhale ontstaan nie in lugleegtes nie maar dra altyd die vingermerke van die tyd waarin dit geskep is. Derdens bewys hierdie verhale dat mense nie sonder verhale kan bestaan nie. Mense bestaan eenvoudig deur verhale, met verhale en in verhale. Deur middel van verhale gee ons sin aan ons bestaan en daarom kan 'n mens dan ook sê: "Sonder verhale vaar niemand wel." Die verhale van die Persiese tydvak het daardie mense van hulpmiddele voorsien om die lewensreis voort te sit.

Die verhale wat in die Persiese tydvak geskep, versamel, geredigeer en uiteindelik gekanoniseer is, is klaarblyklik nie in biblioteke weggebêre nie. Die verhale het boustene geword vir nuwe verhale wat later geskep is. Vergelyk byvoorbeeld die verhaal van Judit wat duidelik gemodelleer is op die Esterverhaal (en ander ouer verhale). Dis duidelik dat gedagtes wat verwoord en neergepen is, nooit uitsterf nie. Hulle bly altyd resoneer in die gemeenskappe wat die verhale lees, bestudeer en oordink. Dit geld ook van ons samelewing en die verhale wat hier in omloop is. ${ }^{2}$

\section{Literatuurverwysings}

Ackroyd, P R 1968. Exile and restoration: A study of Hebrew thought of the sixth century BC. London: SCM.

Albertz, R 1981. Der sozialgeschichtliche Hintergrund des Hiobbuches und der "Babylonischen Theodizee", in Jeremias, J \& Perlitt, L (Hrsg), Die Botschaft und die Boten: Festschrift für Hans Walter Wolff zum 70. Geburtstag, 349372. Neukirchen-Vluyn: Neukirchener Verlag.

Albertz, R 1992. Religionsgeschichte Israels in alttestamentlicher Zeit, Teil 2: Vom Exil bis zu den Makkabäern. Göttingen: Vandenhoeck \& Ruprecht. (Grundrisse zum Alten Testament, Band 8/2.)

Albertz, R 2000. Sozial- und Religionsgeschichte: Folgen der Exilszeit. Bibel und Kirche 55, 127-131.

\footnotetext{
${ }^{2}$ Andries Breytenbach is ' $n$ uitmuntende skepper en oorverteller van verhale daarom dra ek hierdie artikel ook graag aan hom op.
} 
Albertz, R 2003. The thwarted restoration, in Albertz \& Becking 2003:1-17.

Albertz, R \& Becking, B (ed) 2003. Yahwism after the Exile: Perspectives on Israelite religion in the Persian era. Assen: Van Gorcum. (Studies in Theology and Religion, 5).

Balentine, S 1996. The politics of religion in the Persian period, in Barton, J \& Reimer, D J (eds), After the Exile: Essays in honour of Rex Mason, 129-146. Macon: Mercer University Press.

Bandstra, B L 1995. Reading the Old Testament: An introduction to the Hebrew Bible. Belmont: Wadsworth.

Barr, J 1961. The semantics of Biblical language. Oxford: Oxford University Press.

Barr, J 1962. Biblical words for time. London: SCM. (Studies in Biblical Theology. First Series 33.)

Barr, J 2000. History and ideology in the Old Testament: Biblical Studies at the end of a millennium. Oxford: Oxford University Press.

Ben Zvi, E 2003. What is new in Yehud? Some considerations, in Albertz \& Becking 2003:32-48.

Blenkinsopp, J 1983. Wisdom and the law in the Old Testament: The ordering of life in Israel and early Judaism. Oxford: Oxford University Press.

Blenkinsopp, J 1988. Ezra-Nehemiah. London: SCM. (Old Testament Library.)

Bolin, T M 1996. When the end is the beginning: The Persian Period as the origin of biblical tradition. SJOT 10:3-15.

Bosman, H L \& Loader, J A (reds) 1987. Vertellers van die Ou Testament. Kaapstad: Tafelberg. (Die literatuur van die Ou Testament, Deel 2.)

Breytenbach, A P B 1968. 'n Vergelykende studie tussen die onderskeie uitdrukkinge 'ad hajjōm hazzēh en dom nāgī by Jeremia en Deuteronomium. BDverhandeling, Universiteit van Pretoria.

Bright, J 1953. The Kingdom of God: The biblical concept and its meaning for the church. Nashville, TN: Abingdon.

Cataldo, J 2003. Persian policy and the Yehud community during Nehemiah. JSOT 28, 131-143.

Childs, B 1978. The exegetical significance of canon for the study of the Old Testament, in Emerton (ed), Congress Volume Göttingen, 66-80. Leiden: Brill. (VT.S 29.)

Childs, B 1979. Introduction to the Old Testament as Scripture. London: SCM.

Collins, J J 1993. Daniel. Minneapolis, MN: Fortress. (Hermeneia.)

Collins, J J 2001. Current issues in the study of Daniel, in Collins \& Flint 2001:1-15.

Collins, J J \& Flint, P W 2001. The Book of Daniel: Composition and reception, vol I. Leiden: Brill.

Crüsemann, F 1987. Geschichte Israels als Geschichte der Bibel, in Lessing, E (Hrsg), Die Bibel: Das Alte Testament in Bildern erzählt von Erich Lessing, mit Beiträgen von Franz Kardinal König, Rainer Albertz, Frank Crüsemann, Jürgen Ebach und Manfred Görg, 134-168. München: Bertelsmann.

Davies, P R 1985. Daniel. Sheffield. JSOT. (Old Testament Guides.)

Davies, P R 1995. Whose Bible is it anyway? Sheffield: SAP. (JSOT Suppl 204.)

Deist, F E 1971. Die betekenissfeer van die leksikale morfeem /y-r-'/ in die profetiese boeke van die Ou Testament. D Litt-proefskrif, Universiteit van Stellenbosch.

Deist, F E 1997. The Yehud Bible: A belated divine miracle? JNSL 23: 117-142.

Deist, F E 1981. Die God van Jona. Kaapstad: Tafelberg. 
Dever, W G 2001. What did the biblical writers know and when did they know it? Grand Rapids, MI: Eerdmans.

Dommershausen, W 1968. Die Estherrolle. Stuttgart: KBW. (Stuttgarter Biblische Monographien 6.)

Ebach, J 2000. Worte gegen den Tod: Ezechiels Auferstehungsvision (Ez 37). Bibel und Kirche 55, 120-124.

Gerstenberger, E S 2002. Theologies in the Old Testament. London: Continuum.

Gillis, C 1993. Pluralism: A new paradigm for theology. Louvain: Peeters. (Louvain theological and pastoral monographs 12.)

Grabbe, L L (ed) 1998. Leading captivity captive: The "exile" as history and tradition. Sheffield: SAP. (JSOT Suppl 278.)

Grabbe, L L 1992. Judaism from Cyrus to Hadrian. London: SCM.

Grünewaldt, K 1992. Exil und Identität: Beschneidung, Passa und Sabbat in der Priesterschrift. Frankfurt: Athenäums Monografien. (BBB 85).

Hansson, G 1990. Reading and understanding the Bible, in Hansson, G (ed), Bible reading in Sweden: Studies related to the translation of the New Testament 1981, 105-116. Stockholm: Almqvist \& Wiksell.

Humphreys, W L 1973. A life-style for diaspora: A study of the tales of Esther and Daniel. JBL 92, 211-223.

Jagersma, H 1979. Geschiedenis van Israël in het oudtestamentische tÿdvak 1. Kampen: Kok.

Japhet, S 1968. The supposed common authorship of Chronicles and EzraNehemiah investigated anew. VT 18, 330-371.

Joyce, P 1993. A tale of two sisters: Judaism and Christianity. Theology 96, 384-390.

Klein, R P 2001. Narrative Texts: Chronicles, Ezra, and Nehemiah, in Perdue 2001:385-401.

Knauf, E A 2000. Israel/Juda und seine Umwelt: Wie kann ich singen im fremden Land? Bibel und Kirche 55, 132-139.

Knibb, M A 2001. The Book of Daniel in its context, in Collins \& Flint 2001:16-35.

Lemche, N P 1993. The Old Testament: A Hellenistic book? SJOT 7, 163-193.

Le Roux, J H 1987. Teologie in 'n krisis, in Deist, F E \& Le Roux, J H, Rewolusie en reïnterpretasie, 101-159. Kaapstad: Tafelberg. (Die literatuur van die Ou Testament. Deel 4.)

Le Roux, J H 1993 A story of two ways: Thirty years of Old Testament scholarship in South Africa. Pretoria: Verba Vitae. (OTE Suppl 2.)

Loader, J A 1971. QRB as religieuse term in die Ou Testament en die daarvan afhanklike Semitiese literatuur. MA-verhandeling, Universiteit van Pretoria.

Loader, J A 1974. Chokma - Joseph - Hybris. OTWSA 17 \& 18, 21-31.

Loader, J A 1978. Esther as a novel with different levels of meaning. ZAW 90, 417421.

Loader, J A 1980. Esther. Nijkerk: Callenbach. (POT.)

Loader, J A 1987a. Die verhaal van Josef, in Bosman \& Loader 1987:100-107.

Loader, J A 1987b. Rut, in Bosman \& Loader 1987:108-114.

Loader, J A 1987c. Ester, in Bosman \& Loader 1987:115-122.

Loader, J A 1987d. Jona, in Bosman \& Loader 1987:123-127.

Loader, J A 1994. Ruth. Kampen: Kok. (Tekst en Toelichting.)

Maier, C M 2000. Religonsgeschichte (2): Israels Weg zum Monotheismus. Bibel und Kirche 55, 140-146. 
Meinhold, A 1975. Die Gattung der Josephgeschichte und des Estherbuches: Diasporanovelle, I, ZAW 87, 306-324.

Meinhold, A 1976. Die Gattung der Josephgeschichte und des Estherbuches: Diasporanovelle, II, ZAW 88, 72-93.

Nickelsburg, G W E 2003. Ancient Judaism and Christian Origins: Diversity, continuity and transformation. Minneapolis, MN: Fortress.

Perdue, L G 2001. The Blackwell Companion to the Hebrew Bible. Oxford: Blackwell.

Scharbert, J 1988. "Ich bin Josef, euer Bruder": Die Erzählung von Josef und seinen Brüdern, wie sie nicht in der Bibel steht. St. Ottilien: Eos Verlag.

Scheffler, E H 1999. Verskillende boodskappe vir verskillende kontekste: Die literatuur van die ballingskap (597-539 vC). Skrif en Kerk 20, 349-372.

Schneider, S 2000. Mit ander Augen: Galut oder vom Sinn des Exils. Bibel und Kirche 55, 147-151.

Smith, K 1988. The changing past: Trends in South African historical writing. Johannesburg: Southern Book.

Spangenberg, I J J 1994. Paradigmaveranderinge in die Bybelwetenskappe: 'n Bydrae tot die gesprek tussen die Bybelwetenskappe en Sistematiese Teologie. Religion \& Theology 1, 144-184.

Spangenberg, I J J 1998. Op pad na 2000: Oftewel oor al die dinge wat gebeur het. Old Testament Essays 11, 534-566.

Struppe, U 2000. Einführung: Exil - Krise als Chance. Bibel und Kirche 55, 110-119.

Theissen, G 1999. A theory of primitive Christian religion. London: SCM.

Van Dyk, P J 1987. Die kronistiese geskiedwerk, in Bosman \& Loader 1987:75-99.

Vorster, W S 1979a. Aischunomai en stamverwante woorde in die Nuwe Testament. Pretoria: UNISA.

Vorster, W S 1979b. In gesprek met die Landmankommissie oor Skrifgebruik, in Viljoen, A C (red), Ekumene onder die Suiderkruis, 182-208. Pretoria: UNISA

Weinfeld, M 1972. Deuteronomy and the Deuteronomistic school. Oxford: Oxford University Press.

Wessels, J P H 1989. Die Josefverhaal as wysheidsnovelle. Pretoria: Serva.

Williamson, H G M 1987. Ezra and Nehemiah. Sheffield: JSOT. (Old Testament Guides.) 